\title{
The Contributions of Building Information Modelling to Sustainable Construction
}

\author{
Sahar Soltani \\ Department of Art and Architecture, Yazd University, Yazd, Iran \\ Email: s.soltani.ma@gmail.com
}

Received 2 April 2016; accepted 7 May 2016; published 10 May 2016

Copyright (C) 2016 by author and Scientific Research Publishing Inc.

This work is licensed under the Creative Commons Attribution International License (CC BY). http://creativecommons.org/licenses/by/4.0/

(c) (i) Open Access

\begin{abstract}
Global concerns toward environmental issues have induced growing demand for new approaches in the construction because of its considerable impact on the environment and use of natural resources. Through using construction sustainability tools, methods and techniques, a greener design can be applied during various building phases. In this connection, it is argued that the analytical and integrated models applied by Building Information Modelling (BIM) may also facilitate this process to be performed more efficiently. BIM and construction sustainability are quite different initiatives, but both have received much attention in recent years in the architecture, engineering and construction (AEC) industry. A rigorous analysis of the interactions between them implies that a synergy exists which, if properly it is understood that can be helpful to reduce the environmental impacts of the AEC industry. A BIM-based design model can contribute to sustainability through its three main dimensions which are environmental, economic and social. In this paper, by reviewing the existing literature on BIM and construction sustainability and using a matrix to analyze construction sustainability dimensions and BIM functionalities a number of interactions have been discussed. It can be concluded that despite there are many improvements in implementation of BIM in environmental and economic aspects of sustainability, its potential impact on social dimension has not been explicitly explored hence further studies need to be undertaken in this area.
\end{abstract}

\section{Keywords}

Sustainable Construction, Building Information Modelling, BIM, Design for Quality, Project Management

\section{Introduction}

Universally, building and construction industry is responsible for large amounts of energy consumption and 
greenhouse gas emissions [1]. Accordingly, the application of sustainable construction is becoming a mainstream concern to be mandated by nations and government through various legislations to move towards an environmentally sustainable future [2].

Technological innovation plays a key role in both short and long-term economic, societal and environmental sustainability. In recent years, BIM has been considered as one of the most effective technological and organizational innovation in the AEC industry [3]. According to the US National BIM Standard (2007) [4], BIM can be discussed as three main dimensions; 1) a product to describe a building; 2) a process of information; and 3) a system through which the efficiency and quality of a structure are increased. BIM technology can facilitate sustainable building in various design phases from the initiation stage to demolition by providing an integrated design workflow in each stage [5] [6]. For instance, it enables the energy-efficient and cost-effective design through which a greener and more accurate design can be applied [7]. This is especially critical in huge projects with complex performance assessment that through providing a more sustainable construction in its different dimensions, a healthier community can be gained with the promotion of their quality of life. In this connection, the contribution of BIM to construction sustainability can be even more indispensable by applying BIM technology in social dimension and its role in addressing cultural values in a society. As Kohler (1999) discussed, to understand national specification, a deeper understanding of cultural differences is needed along with other environmental concerns [8]. Moreover, the concept of growth and prosperous economic is not exclusively constrained to the activities that lead to economic benefit in short-terms which are admired as industrialization and consumption values. A wider prospect toward long-term societal well-being is required to gain a truly developing sustainable community through cherishing conventional and cultural values [9] [10].

\section{Methodology}

This paper presents a literature review of the interaction of BIM and sustainability. The review covers journals, conference proceedings, master and doctoral dissertation, and book chapters which were dated from 1998 to 2015 extracted from data bases such as Science Direct, Taylor and Francis, etc. Moreover, the literature search was based on their scopes and definitions of these concepts and their interaction and collaboration. For sustainability, the articles focused on its three dimensions including environmental, economic, and social were studied to categorize various principles for each dimension. Subsequently, by extracting BIM and sustainable contributions to design, its specific analytical models and tools were compared and contrasted with sustainability principles. Finally, the relationship between BIM and sustainable construction were discussed to explore the gaps in the existing knowledge, especially in social dimensions of BIM-based sustainable analysis in both research and practical areas.

\section{Sustainability}

Humans are constantly influencing their surrounded environment and are affected by it. Sustainable development provides the conditions for a healthy life regarding present people's needs as well as future generation by improving social, economic and environmental condition [11]. The worldwide attention to the effect of construction on the environment has increased the requirements for sustainable developments. The important objective of designing built environment is to study this interaction and find measurements to control and manage it properly so that the quality of life can be improved throughout various methods and strategies such as sustainable design [2].

During recent years, constructing buildings have had various harmful effects on the environment and ecosystem due to the limited sources of materials and biological capacity. This process has been so quick and harsh that it has hampered resources to be renewed and compensated. It is a huge responsibility and challenge for present occupants of the earth to consider its carrying capacity and manage it in a way that does not deprive future generation to meet their needs, so the aim of sustainable development is also to find long-term solutions to support humans' existence and well-being [12].

\section{Implementation of Sustainability in Construction}

The Coseil International du Batiment (CIB) defines sustainable construction according to its dependency on resources and ecological principles in order to build and operate a healthy environment. CIB also introduces seven 
elements through which the whole life cycle of a building can be considered in various stages of construction sustainabi1ity. These elements include: reducing resource consumption, reusing resources, using recyclable resources, protection nature, eliminating toxics, applying life-cycle costing and emphasizing quality [13].

The concept of sustainable construction can also be considered with two main goals: 1 ) to decrease the effects of building on environment from its birth to death; and 2) to focus on psychological and physical well-being of people through socially responsible and sustainable design [9].

Different conceptual frameworks have been suggested for better understanding of sustainability implication. John Elkinton (1998) considered the concept of sustainability with three main dimensions which is called as "the triple line" and includes: economic, social and environmental aspects [14]. Hill and Bowen (1997) proposed social, economic, biophysical and technical dimensions for implementing sustainable construction principles [15].

Jong-Jin Kim (1998) suggested a more different model with three principles whose combination in diverse construction phases can lead to sustainable design. Economy of resources, life cycle design and human design comprising a framework with three levels related to the three objectives of architectural environmental education, and introduced methods for each principle. While the economy of resources corresponds to energy, water and material conservation, life cycle design is concerned with pre-building, building and post-building phase. The last but not the least principle is human design that focuses on preservation of natural conditions, urban design, site planning and design for human comfort [10].

Nicklaus Kohler (1999) presented a framework based on three dimensions of sustainability which are: ecological, economic and social and cultural sustainability. Even though this category is very similar to the others, there are some differences in their definition, especially in the social and cultural dimensions. The ecological sustainability in this framework is related to the protection of resources and the ecosystem. In the economical dimension, the durability and reusability in the long-term is superior to low cost highly customized measurements, so it corresponds with long-term resource productivity and low running costs. The social and cultural dimension is consisted of protection of comfort and health, and preservation of social and cultural values. Indeed, this definition of social principle regards a unique attention into the cultural values of human-made environment conservation related to building stock as precious heritages in conjunction with human health, well-being and comfort protection [8].

In a more recent study, Kats and Alevantis (2003) reviewed some potential benefits in applying sustainable design into construction process in its three dimensions. In the environmental aspect the advantages are generally cover the improving quality of air and water as well as optimizing the usage of energy and water resources. Dec1ining the operation and maintenance costs can benefit economic dimension. Their definition of social sustainability merits also is not far away from other frameworks which are consisted of benefiting community by improving health indicators such as occupant comfort [16].

Manoliadis and slas (2006) postulated the following elements that are essential for motivating stakeholders to embrace sustainable design during their projects: "energy conservation, waste reduction, indoor environmentally quality, environmentally-friendly energy technologies, resource conservation, incentive programmes, performance-based on standards, land use regulations and urban planning polices, education and training, re-engineering the design process, sustainable construction materials, new cost metrics based on economic and ecological value systems, new kinds of partnerships and project stakeholders, product innovation and/or certification and recognition of commercial buildings as productivity assets [17]”.

In another study, Paola Sassi (2006) suggested six features of sustainable design which are land use, community, health and well-being, material, energy and water, all of which were elaborated in their role and influence as well as practical guidelines by introducing case studies as proper specimens of each feature with their common objective of creating a better living environment, and are socially responsible and economically viable [9]. Thus, the economic progress is integrated with other aspects of sustainability in this framework; developing in other dimensions contributes to economic prosperity.

All of the above-mentioned frameworks aimed to embody the principals of sustainable development in the AEC industry. Nevertheless, one of the most well-known models is the one presented by Elkinston which consider sustainability in three dimensions based on their fundamental similarities. It seems also important to mention that in spite of their separated boundaries, each dimension or principle shares common scopes with others. In this study, we use Elkinston's model since not only this model is one of the widely accepted one but also it facilitates the comparison with BIM functionalities (Table 1). 
Table 1. Comparison of various conceptual frameworks for sustainable construction factors.

\begin{tabular}{|c|c|c|c|c|c|}
\hline $\begin{array}{l}\text { Elkinton } \\
\text { (1998) }\end{array}$ & $\begin{array}{c}\text { Sassi } \\
(2006)\end{array}$ & $\begin{array}{l}\text { Hill and Bown } \\
\text { (1997) }\end{array}$ & $\begin{array}{l}\text { Kohler } \\
\text { (1999) }\end{array}$ & $\begin{array}{l}\text { Kim } \\
\text { (1998) }\end{array}$ & $\begin{array}{c}\text { Kats and Alevantis } \\
\text { (2003) }\end{array}$ \\
\hline Environmental & $\begin{array}{l}\text {-Site and land use } \\
\text {-Materials } \\
\text {-Energy } \\
\text {-Water }\end{array}$ & Biophysical & $\begin{array}{l}\text { Ecological } \\
\text { a) Protection of resources } \\
\text { b) Protection of ecosystem }\end{array}$ & Life cycle design & $\begin{array}{l}\text { Environmental } \\
\text { (Air, water, } \\
\text { energy...) }\end{array}$ \\
\hline Economic & & $\begin{array}{l}\text {-Economic } \\
\text {-Technical }\end{array}$ & $\begin{array}{l}\text { Economic } \\
\text { a) Long-term resources } \\
\text { productivity } \\
\text { b) Low running costs }\end{array}$ & $\begin{array}{l}\text { Economy of } \\
\text { resources }\end{array}$ & $\begin{array}{l}\text { Economic } \\
\text { a) Operating cost } \\
\text { b) Maintenance cost } \\
\text { Revenue }\end{array}$ \\
\hline Social & $\begin{array}{l}\text {-Community } \\
\text {-Health and } \\
\text { well-being }\end{array}$ & Social & $\begin{array}{l}\text { Social and Cultural } \\
\text { a) Protection of comfort and } \\
\text { health } \\
\text { b) Preservation of social and } \\
\text { cultural values }\end{array}$ & Human design & $\begin{array}{l}\text { Health and } \\
\text { Community } \\
\text { a) Comfort } \\
\text { b) Health }\end{array}$ \\
\hline
\end{tabular}

\section{Building Information Modelling}

There is no consensus among the researchers regarding the definition of BIM [18]. However, one of the most widely accepted definition of BIM is presented by Eastman (2008). They defined Building Information Modelling (BIM) as "a digital representation of the building process to facilitate exchange and interoperability of information in digital format" [19]. BIM can be considered as simulating a building project from the initiation stage to demolition and providing a 3D virtual environment with a workflow of integrated information through a software package [20] [21]. Integrating the deliverables in a model, BIM can predict and decrease problems and errors. The model provides various analytical information for the visualized design which can contribute to digital fabrication and facilitated management [20].

\section{BIM-Based Analysis in Sustainability}

As it is discussed previously, BIM can conduct operation on multi-disciplinary data within one model. This feature enables performing process on sustainability measures due to their complicated designing and delivering performances [22]. Accordingly, BIM has become an integral part of sustainability analysis and simulation, and plays an important role in decreasing industry waste and environmental harms [7]. Therefore, the demand for BIM-based analysis in the field of sustainability is increasing dramatically. BIM technology, along with its general uses, can contribute to sustainable construction in various stages of a building project from making important decisions in early phases to demolition to enhance the productivity and performance [23]. In regards to sustainable construction, the contribution of BIM to building process can be compared with the three main dimensions of the sustainability: environmental, economic and social.

\subsection{Economic Dimension}

One of the main contributions of BIM to sustainable construction, which also is one of its general uses, is its direct role in economic dimension by the process of cost estimating and risk management [21]. Estimating the costs of the project and required resources can be divided into some stages to predict and calculate the costs of each phase [24]. Moreover, to reduce costs of a project, in addition to the 3D models of BIM representations, project managers can incorporate time in their analysis as 4D models to estimate the projects' risks more efficiently and effectively [25]. Even though this process can aid the project to be progressive and cost effective, it would not be considered as a sustainable approach unless it includes the benefit of the environment and the concept of promoting the quality of life in its calculation, and put the human well-being and socially-oriented values in their priorities [9].

Furthermore, the implementation of BIM on other aspects of the project can have an influential role in economic efficiency. For instance, predicting the future detects and enhancing collaboration and communication among stakeholders lead to reducing wastage, saving time, promoting building management and subsequently decreasing projects costs [19] [21]. 


\subsection{Environmental Dimension}

Within BIM, much of the data required for supporting performance analysis is captured naturally as design on the project proceeds. By using a building information model, designers can analyse how a building will perform in the very early stages of design and based on that, they can quickly assess design alternatives to make a better decision to iterate on a greener design [26]. Most of BIM tools have various features for evaluating energy and material consumption analysis and electrical and mechanical portion of the building so that it would create explicit information on decreasing the wastage of energy and resources [7]. Some of the BIM software such as Autodesk Ecotect and Revit provide some common tools that process information to analyse environmental features of the project. This further enables architects and designer to manage energy usage and exploit resources efficiently. Providing analysis on solar path, building orientation, shading design and heating and cooling determination, such software can integrate data to achieve a greener design [7] [22].

\subsection{Social Dimension}

The Western Australia Council of Social Services (WACOSS) defines the occurrence of social sustainability: “...when the formal and informal processes; systems; structures; and relationships actively support the capacity of current and future generations to create healthy and livable communities. Socially sustainable communities are equitable, diverse, connected and democratic and provide a good quality of life [27]".

Generally the benefits of sustainability for social aspects are considered within improvement on other aspects of sustainability which results in promoting human well-being, comfort and health [9] [28]. In regards to sustainability, the social principle addresses a wide spectrum of concepts and definitions which can be divided into two groups in terms of interaction with BIM; dependent and independent features. Dependent features of the social sustainability are more quantitative and can directly be measured through other assessments which BIM can provide for various aspects of the environmental condition such as energy performance and lighting (Table 2). According to Sassi, improving some environmental features through sustainable design induce health and performance promoting, whereas negative condition can foster health disorders such as stress, discomfort and absenteeism. Consequently, the overall effects of such considerations benefit the whole community and society.

On the other hand, most of the definitions and concepts suggested as socially sustainable design are independent from other variables which chiefly are qualitative. Sassi (2006) categorized a part of such qualities as features of sustainability related to community, and categorizes the other aspects of health and well-being as the opportunities for social interaction, the sense of self-worth of individuals and the sense of belonging to the place.

There are other ways that sustainable design can improve the quality of life in the society scale which generally are knowledge transfer, improved environmental quality, neighborhood restoration and reduced health risks from pollutants associated with building energy use [28].

\begin{tabular}{|c|c|c|c|}
\hline Sustainability Dimensions & Sustainability Factors & BIM Implementation & BIM Examples \\
\hline Environmental & $\begin{array}{l}\text { Site and Land Use } \\
\text { Materials } \\
\text { Energy } \\
\text { Water } \\
\text { Air }\end{array}$ & $\begin{array}{c}\text { Orientation } \\
\text { Shadow } \\
\text { Light Path } \\
\text { Heating and Cooling Load Analysis }\end{array}$ & $\begin{array}{c}\text { Ecotect } \\
\text { Revit } \\
\text { Energy Plus } \\
\text { Green Building Studio }{ }^{\mathrm{TM}}(\mathrm{GBS}) \\
\text { Virtual Environment }^{\text {Giron }}\end{array}$ \\
\hline Economic & $\begin{array}{l}\text { Long-term Resources Productivity } \\
\text { Low running Costs } \\
\text { Operating Cost } \\
\text { Maintenance Cost } \\
\text { Revenue }\end{array}$ & $\begin{array}{c}\text { Cost Estimation } \\
\text { Quantity Surveying }\end{array}$ & $\begin{array}{c}\text { Cost X } \\
\text { Total Project Logistics } \\
\text { Resi-Cost } \\
\text { Chief Estimator } \\
\text { Quantity Take off }\end{array}$ \\
\hline Dependent & $\begin{array}{c}\text { Health } \\
\text { Well-being } \\
\text { Comfort }\end{array}$ & $\begin{array}{c}\text { Orientation } \\
\text { Shadow } \\
\text { Light Path } \\
\text { Heating and Cooling Load Analysis }\end{array}$ & $\begin{array}{c}\text { Ecotect } \\
\text { Revit } \\
\text { Energy Plus } \\
\text { Green Building Studio }^{\mathrm{TM}}(\mathrm{GBS}) \\
\text { Virtual Environment }^{\text {Viron }}\end{array}$ \\
\hline Independent & $\begin{array}{c}\text { Social and Cultural Values } \\
\text { Human Design } \\
\text { Community }\end{array}$ & & \\
\hline
\end{tabular}




\section{Discussion and Conclusion}

The aim of this paper is to review different ways through which BIM can interact with sustainable design, explore the gaps in its theoretical and practical scopes and highlight the important implications for related practitioners and researchers. Because of the limited numbers of reviewed papers, this study cannot claim to be comprehensive. However, it has shed light on the interaction of BIM and construction sustainability. Based on this review, it is found that despite the abundance of the research in both areas of BIM and construction sustainability, the interaction of these two concepts has not well explored. In particular, among the three dimensions of sustainability, social dimension and the way BIM may have influences on it, have received less attention. However, due to the importance of this aspect, future research can be conducted to further explore whether BIM implementation has any significant impact on the construction sustainability through social aspects. To fulfill this aim, the use of social theories such as Space Syntax [29], which provides a systematic and explicit social framework along with its analytical applications like UCL DepthMap [30] can be helpful.

\section{References}

[1] http://communicate.usgbc.org/2008/

[2] Ortiz, O., Castells, F. and Sonnemann, G. (2009) Sustainability in the Construction Industry: A Review of Recent Developments Based on LCA. Construction and Building Materials, 23, 28-39. http://dx.doi.org/10.1016/j.conbuildmat.2007.11.012

[3] Succar, B. and Kassem, M. (2015) Macro-BIM Adoption: Conceptual Structures. Automation in Construction, 57, 6479. http://dx.doi.org/10.1016/j.autcon.2015.04.018

[4] https://www.wbdg.org/pdfs/NBIMSv1_p1.pdf

[5] Häkkinen, T. and Kiviniemi, A. (2008) Sustainable Building and BIM. Proceedings of SB08 Conference Melbourne, Melbourne, 25 September 2008, 21-25.

[6] Kivits, R.A. and Furneaux, C. (2013) BIM: Enabling Sustainability and Asset Management through Knowledge Management. The Scientific World Journal, 2013, Article ID: 983721. http://dx.doi.org/10.1155/2013/983721

[7] Wong, K.D. and Fan, Q. (2013) Building Information Modelling (BIM) for Sustainable Building Design. Facilities, 31, 138-157. http://dx.doi.org/10.1108/02632771311299412

[8] Kohler, N. (1999) The Relevance of Green Building Challenge: An Observer's Perspective. Building Research \& Information, 27, 309-320. http://dx.doi.org/10.1080/096132199369426

[9] Sassi, P. (2006) Strategies for Sustainable Architecture/Paola Sassi. Taylor \& Francis, Oxford.

[10] Kim, J.J. and Rigdon, B. (1998) Education, Sustainable Architecture Module: Introduction to Sustainable Design. National Pollution Prevention Center for Higher Education.

[11] World Commission on Environment and Development (1987) Our Common Future. Oxford University Press, Oxford, New York.

[12] Olgyay, V. and Herdt, J. (2004) The Application of Ecosystems Services Criteria for Green Building Assessment. Solar Energy, 77, 389-398. http://dx.doi.org/10.1016/j.solener.2004.01.011

[13] Kibert, C.J. (2012) Sustainable Construction: Green Building Design and Delivery. John Wiley \& Sons, Hoboken.

[14] Elkington, J. (1998) Cannibals with Forks: The Triple Bottom Line of 21st Century Business. New Society Publishers, Gabriola Island, Stony Creek.

[15] Ofori, G. (1998) Sustainable Construction: Principles and a Framework for Attainment-Comment. Construction Management and Economics, 16, 141-145. http://dx.doi.org/10.1080/014461998372448

[16] Kats, G., Alevantis, L., Berman, A., Mills, E. and Perlman, J. (2003) The Costs and Financial Benefits of Green Buildings. A Report to California's Sustainable Building Task Force.

[17] Manoliadis, O., Tsolas, I. and Nakou, A. (2006) Sustainable Construction and Drivers of Change in Greece: A Delphi Study. Construction Management and Economics, 24, 113-120. http://dx.doi.org/10.1080/01446190500204804

[18] Abbasnejad, B. and Moud, H.I. (2013) BIM and Basic Challenges Associated with Its Definitions, Interpretations and Expectations. International Journal of Engineering Research and Applications (IJERA), 3, 287-294.

[19] Eastman, C., Eastman, C.M., Teicholz, P. and Sacks, R. (2011) BIM Handbook: A Guide to Building Information Modeling for Owners, Managers, Designers, Engineers and Contractors. John Wiley \& Sons, Hoboken.

[20] Grilo, A. and Jardim-Goncalves, R. (2010) Value Proposition on Interoperability of BIM and Collaborative Working Environments. Automation in Construction, 19, 522-530. http://dx.doi.org/10.1016/j.autcon.2009.11.003 
[21] Hartmann, T., van Meerveld, H., Vossebeld, N. and Adriaanse, A. (2012) Aligning Building Information Model Tools and Construction Management Methods. Automation in Construction, 22, 605-613. http://dx.doi.org/10.1016/j.autcon.2011.12.011

[22] Azhar, S., Brown, J. and Farooqui, R. (2009) BIM-Based Sustainability Analysis: An Evaluation of Building Performance Analysis Software. Proceedings of the 45th ASC Annual Conference, Gainesville, 1-4 April 2009.

[23] Azhar, S. and Brown, J. (2009) BIM for Sustainability Analyses. International Journal of Construction Education and Research, 5, 276-292. http://dx.doi.org/10.1080/15578770903355657

[24] Halpin, D.W. and Woodhead, R.W. (1998) Construction Management. Wiley, New York.

[25] Zhang, J.P. and Hu, Z.Z. (2011) BIM- and 4D-Based Integrated Solution of Analysis and Management for Conflicts and Structural Safety Problems during Construction: 1. Principles and Methodologies. Automation in Construction, 20, 155-166. http://dx.doi.org/10.1016/j.autcon.2010.09.013

[26] Azhar, S., Carlton, W.A., Olsen, D. and Ahmad, I. (2011) Building Information Modeling for Sustainable Design and LEED ${ }^{\circledR}$ Rating Analysis. Automation in Construction, 20, 217-224. http://dx.doi.org/10.1016/j.autcon.2010.09.019

[27] http://www.wacoss.org.au/about_wacoss/about_wacoss.aspx

[28] https://www1.eere.energy.gov/femp/pdfs/buscase_section3.pdf

[29] Hillier, B. and Hanson, J. (1984) The Social Logic of Space. Cambridge University Press, Cambridge, New York.

[30] Penn, A. and Turner, A. (2003) Space Syntax Based Agent Simulation. Bartlett School of Graduate Studies, London. 